medRxiv preprint doi: https://doi.org/10.1101/2022.01.26.22269869; this version posted January $28,2022$. The copyright holder for this preprint (which was not certified by peer review) is the author/funder, who has granted medRxiv a license to display the preprint in perpetuity.

It is made available under a CC-BY 4.0 International license.

Schistosomiasis in Rwanda pre-SAC

\title{
1 Prevalence mapping of Schistosomiasis among Pre-school aged children in \\ 2 Rwanda
}

3

4 Bayingana Jean Bosco ${ }^{1,2}$, Nyandwi Elias ${ }^{3}$, Ntakarutimana Amans ${ }^{2}$, Kagabo Joseph ${ }^{2}$, Shema

5 Eliah $^{2}$, Kanimba Philbert ${ }^{2}$, Mbonigaba Jean Bosco ${ }^{4}$, Ruberanziza Eugene ${ }^{4} \&$ Rujeni Nadine ${ }^{2 \#}$

6

$7 \quad{ }^{1}$ University of Rwanda, Single Project Implementation Unit

$8 \quad{ }^{2}$ University of Rwanda, College of Medicine and Health Sciences, School of Health Sciences

93 University of Rwanda, College of Science and Technology, Centre for Geographic

10 Information Systems and Remote Sensing (CGIS)

$11{ }^{4}$ Ministry of Health, Rwanda Biomedical Center, NTDs \& Other Parasitic Diseases Unit

12

13 \#Corresponding author email address: nrujeni@gmail.com 
medRxiv preprint doi: https://doi.org/10.1101/2022.01.26.22269869; this version posted January 28, 2022. The copyright holder for this preprint (which was not certified by peer review) is the author/funder, who has granted medRxiv a license to display the preprint in perpetuity.

It is made available under a CC-BY 4.0 International license.

Schistosomiasis in Rwanda pre-SAC

16

17

18

19

20

21

\section{Abstract}

Schistosomiasis is endemic in Rwanda and control programs have been implemented with a special focus on school-aged children (SAC) ignoring pre-school aged children (pre-SAC) for which the actual prevalence of the disease is not well established. This study consisted of a cross-sectional quantitative mapping of the distribution of schistosomiasis and identification of associated risk factors among pre-SAC throughout the country. The study covered all the 17 Districts of Rwanda endemic for schistosomiasis with a total sample of 4675 children enrolled from 80 purposively selected villages. The Parasitological assessment of children's urine and stool samples was conducted using CCA and Kato Katz methods respectively for infection detection. A standard questionnaire was used to collect data on the risk factors and geospatial assessment was performed using tablets and GPS to record geographic coordinates for plotting locations on maps using ArcGIS software.

The overall prevalence of $S$ mansoni infection across the surveyed areas was $24 \%$ and 0.8 by CCA and Kato-Katz, respectively. Infection was significantly associated with bathing children in open water bodies. Furthermore, pre-SAC looked after by siblings (sisters) were twice as much likely to be infected compared to those looked after by mothers. Schistosomiasis control interventions are needed for pre-SAC to limit their exposure to open water bodies with expectations of adapted chemotherapy to be availed. Community based deworming campaigns may be the best way to ensure good treatment coverage of pre-SAC in Rwanda.

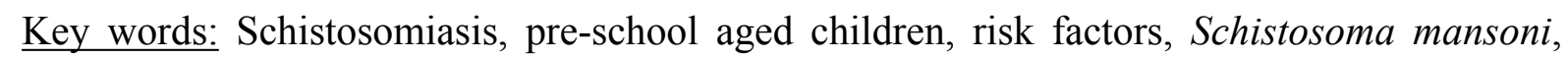
Rwanda 
medRxiv preprint doi: https://doi.org/10.1101/2022.01.26.22269869; this version posted January 28, 2022. The copyright holder for this preprint (which was not certified by peer review) is the author/funder, who has granted medRxiv a license to display the preprint in

perpetuity.
It is made available under a CC-BY 4.0 International license.

Schistosomiasis in Rwanda pre-SAC

39

40

41

42

\section{Author summary}

Schistosomiasis is one of the Neglected Tropical Diseases (NTD) of public health concern in Rwanda like in many tropical countries. The recently published NTD roadmap by the World Health Organization indicates that schistosomiasis is targeted for elimination as a public health problem worldwide by 2030 . For this target to be achieved, all at risk populations should be reached by control programs' interventions such as preventive chemotherapy, health education as well as water, sanitation and hygiene (WASH) practices. However, preschool children (pre-SAC) are among populations at risk for whom infection burden is not fully documented. Implementation of the recent WHO guideline on schistosomiasis control and elimination that recommend inclusion of pre-SAC in control programs will be informed by detailed assessment of the infection burden and distribution in endemic countries. This study is showing for the first time a high burden of schistosomiasis among pre-SAC in highrisk areas of Rwanda. With the imminent availability of the paediatric formulation of Praziquantel (the drug of choice against the disease), the findings should guide the country in implementation strategies that include these children in mass deworming. The findings also highlight a number of risk factors including the passive exposure of these young children by their siblings while bathing them in open waters and the lack of knowledge of parents/guardians on the disease. Additional integrated interventions such as health education, improvement of water supply and sanitation as well as snail surveillance will lead to more sustainable solutions in the march towards schistosomiasis elimination. 
medRxiv preprint doi: https://doi.org/10.1101/2022.01.26.22269869; this version posted January 28, 2022. The copyright holder for this preprint (which was not certified by peer review) is the author/funder, who has granted medRxiv a license to display the preprint in perpetuity.

It is made available under a CC-BY 4.0 International license.

Schistosomiasis in Rwanda pre-SAC

60

61

\section{Introduction}

62 Schistosomiasis is a chronic parasitic infection that is caused by trematodes of the genus Schistosoma, transmitted through fresh water snails. It can cause vascular damage in individuals and is associated with growth retardation and impaired metabolism and cognition $(1,2)$. Schistosomiasis remains a public health concern and highly prevalent in low and middle-income countries, including Rwanda, mostly affecting poor communities with no access to potable water (3). Globally, more than 250 million people are affected by schistosomiasis and Sub Saharan Africa accounts for $90 \%$ of all these infection burdens $(4,5)$. Control interventions mainly rely on regular targeted treatments (using Praziquantel) of populations in endemic areas coupled with health education. Although the disease is targeted (as per the WHO roadmap) for elimination as a public health problem (defined as prevalence of $<1 \%$ of heavy intensity schistosomiasis infections) by 2030 (6), control interventions do not currently reach all populations in need in most endemic areas.

For many years, pre-school aged children (pre-SAC) have been left out in most schistosomiasis treatment programs. This was partly due to the assumption that they are not at great risk of contracting schistosomiasis. However, considerable advances have been made in this regard and a number of studies have shown that most of the pre-SAC in endemic areas are significantly exposed to schistosomiasis in many countries (7-14). This has prompted the WHO to formulate a new guideline including recommendations to include pre-SAC aged 2 years + in preventive chemotherapy while those below 2 years should be treated on individual basis (15). 
medRxiv preprint doi: https://doi.org/10.1101/2022.01.26.22269869; this version posted January 28, 2022. The copyright holder for this preprint (which was not certified by peer review) is the author/funder, who has granted medRxiv a license to display the preprint in

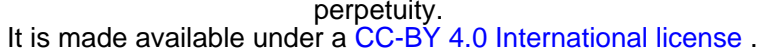

Schistosomiasis in Rwanda pre-SAC

84 With the realization that pre-SAC are in need of treatment, came a number of challenges including the absence of an appropriate child friendly formulation of Praziquantel and the lack of information on the real burden of schistosomiasis in this young age group in some countries. Indeed, inclusion of pre-SAC in schistosomiasis control programs should be justified by quantification of the burden of infection in that age group in each country for optimal intervention. Furthermore, an assessment of their accessibility and local acceptability should guide implementation strategies.

Rwanda is among the countries where the burden of schistosomiasis among pre-SAC is not well documented. Our own study on Nkombo Island in the western part of the country reported an overall prevalence of $9.5 \%$ (9), but a countrywide assessment of the disease in this age group is necessary to better inform the control program. Nevertheless, the Rwandan Ministry of health has recently introduced a community-based deworming strategy whereby community health workers (CHWs) and community leaders coordinate MDAs with minimal supervision from the central level. Such a deworming strategy should be suitable for treating schistosomiasis among pre-SAC.

In light of the above, this study was conducted to estimate the prevalence, identify risk factors and produce an illustrative, countrywide map of schistosomiasis distribution in all moderate to high - risk areas of the country. 
medRxiv preprint doi: https://doi.org/10.1101/2022.01.26.22269869; this version posted January 28, 2022. The copyright holder for this preprint (which was not certified by peer review) is the author/funder, who has granted medRxiv a license to display the preprint in perpetuity.

Schistosomiasis in Rwanda pre-SAC

\section{Methods}

\section{Study design, population, and sample size}

This was a cross-sectional quantitative study that involved parasitological assessment of schistosomiasis among children aged 7 to 59 months. Structured interviews were also held with participants' parents/caregivers to assess risk factors of infection in this young population. The study covered all the 17 Districts of Rwanda at moderate to high risk of schistosomiasis $(16,17)$ and targeted 40 Sectors reported with a prevalence of $10 \%$ and above among school children (based on incidence and mapping data). From each targeted sector, 2 villages were selected based on their proximity to existing water body and/or wetlands. The villages layer was overlaid with layers of lakes, multipurpose water dam, fish pond and/or important wetlands (wetland of $\geq 0.7$ ha hosting a socio-economic activity, mostly irrigated agriculture). From eligible villages (risky villages), final selection was purposively decided considering the spatial distribution pattern analysed visually by researchers and complemented with field verification, making 80 study villages with proximity to open water sources and wetlands. A total of 4675 children were enrolled from the selected villages.

\section{Parasitological assessment}

Urine samples were collected and tested for schistosomiasis circulating antigen using the Point-Of-Care Circulating Cathodic Antigen (POC-CCA or CCA) following manufacturer's instructions. CCA test results were recorded as negative (- or trace) or positive $(+;++$ or +++ according to the intensity of the test line in comparison to a test control). Stool samples were also collected and tested using the Kato Katz method for the detection of patient infection following published protocols (18). A single specimen was collected from which 2 slides were prepared and read by 2 laboratory technicians independently. Ten per cent $(10 \%)$ of all 
medRxiv preprint doi: https://doi.org/10.1101/2022.01.26.22269869; this version posted January 28, 2022. The copyright holder for this preprint (which was not certified by peer review) is the author/funder, who has granted medRxiv a license to display the preprint in perpetuity.

slides were re-tested by the National Reference Laboratory senior technicians for quality control.

\section{Risk factors and spatial assessment}

A standard questionnaire was designed in Kobo toolbox and used to collect data from parents/guardians by a well-trained data collector using a tablet. Geographic coordinates were recorded using tablets and ArcGIS software version 10.4 was used to produce maps.

\section{Statistical analysis}

Data collected were analysed by Stata 13 (STATA Corp, Lakeway, College Station, Texas, USA). Descriptive analysis was conducted. Categorical variables were presented as frequencies and their respective percentages. Numerical variables were presented as mean and standard deviations. For comparison purposes, cross-tabulation analyses were conducted and contingency tables were produced, while chi-square tests were used to compare proportions. To assess the association between variables, logistic regression was performed. For binary logistic regression, each risk factor was assessed with the outcome (infection status) separately while for multivariable logistic regression, a backward stepwise logistic regression was run and all risk factors with a p-value less or equal to 0.05 were considered. Odds ratios and the corresponding 95\% confidence interval (CI) were reported. A two-tailed significance level of 0.05 was considered.

\section{Ethical consideration}

152 The current study was approved by the Institutional Review Board (IRB) of the University of

153 Rwanda College of Medicine and Health Sciences (Approval Notice No 148/CMHS/IRB/2019) and endorsed by the Ministry of Health. Local authorities, community 
medRxiv preprint doi: https://doi.org/10.1101/2022.01.26.22269869; this version posted January $28,2022$. The copyright holder for this preprint (which was not certified by peer review) is the author/funder, who has granted medRxiv a license to display the preprint in It is made available under a CC-BY 4.0 International license .

Schistosomiasis in Rwanda pre-SAC

155

156

157

158

159

160

161

162

163

164

165

166

167

168

169

170

8

health workers and parents/guardians were informed about the aims, voluntary nature of their participation, potential risks and benefits of the study. A signed consent was obtained from parents/guardians before enrolling their child(ren) in the study.

\section{Results}

The results of this research are presented by study sites and do not represent the administrative District. Study sites are those sites in proximity with open water bodies and vary in number per District from one to six. These sites are the base for defining the targeted areas of control interventions.

\section{Demographic characteristics of the study participants}

The total sample was 4675 pre-SAC with a mean age of 37.5 months $( \pm 13.0)$, and a sex ratio M:F of 1.01: 1 (Table 1). Majority of the study participants (corresponding to $96.2 \%$ ) were born in their respective villages (permanent residents). 
medRxiv preprint doi: https://doi.org/10.1101/2022.01.26.22269869; this version posted January $28,2022$. The copyright holder for this preprint (which was not certified by peer review) is the author/funder, who has granted medRxiv a license to display the preprint in perpetuity.

It is made available under a CC-BY 4.0 International license.

Schistosomiasis in Rwanda pre-SAC

172 Table 1. Characteristics of pre-school aged children enrolled in the study

$\mathbf{n}$

$\%$

Age in months (Mean, SD)

$(37.5,13.0)$

Age categories (in months)

12 months and less

$73 \quad 1.6$

13-24 months

842

18

25-36 months

1230

26.3

37-48 months

1359

29.1

49 months and above

1171

25

Total

4675

100

Sex

Female

Male

Total

4675

100

\section{Child born in village}

No

177

3.8

Yes

4498

96.2

Total

4675

100 
medRxiv preprint doi: https://doi.org/10.1101/2022.01.26.22269869; this version posted January 28, 2022. The copyright holder for this preprint (which was not certified by peer review) is the author/funder, who has granted medRxiv a license to display the preprint in perpetuity.

It is made available under a CC-BY 4.0 International license.

Schistosomiasis in Rwanda pre-SAC

176 Water contact activities (exposure) for children in study areas

177 More than $90 \%$ parents reported farming as their occupation and $83.3 \%(n=3895)$ of the

178 families use open water sources (lake, dam or swamp) for daily domestic activities. This

179 result in more than $60 \%$ of enrolled children being regularly in contact with open water

180 sources (Table 2).

181

182

183 Table 2. Water contact activities for parents and their children in the study areas

\begin{tabular}{|c|c|c|}
\hline & $\mathbf{n}$ & $\%$ \\
\hline \multicolumn{3}{|l|}{ Parent's occupation } \\
\hline Casual worker & 143 & 3.18 \\
\hline Farmer & 4,060 & 90.26 \\
\hline Government employee & 52 & 1.16 \\
\hline Self employed & 157 & 3.49 \\
\hline Unemployed & 86 & 1.91 \\
\hline Total & 4,498 & 100 \\
\hline \multicolumn{3}{|c|}{ Fetching water in the open water source } \\
\hline No & 780 & 16.7 \\
\hline Yes & 3895 & 83.3 \\
\hline Total & 4675 & 100 \\
\hline \multicolumn{3}{|c|}{ Child taken to open water source } \\
\hline No & 1444 & 30.9 \\
\hline Yes & 3222 & 69.1 \\
\hline Total & 4666 & 100 \\
\hline \multicolumn{3}{|c|}{ Frequency child taken to lake } \\
\hline Once a day & 2055 & 63.4 \\
\hline Once a week & 824 & 25.4 \\
\hline Once a month & 185 & 5.7 \\
\hline Once a year & 53 & 1.6 \\
\hline Once in his life & 123 & 3.8 \\
\hline Total & 3240 & 100 \\
\hline \multicolumn{3}{|l|}{ Child bathed in the lake } \\
\hline No & 1669 & 36.2 \\
\hline Yes & 2937 & 63.8 \\
\hline Total & 4606 & 100 \\
\hline \multicolumn{3}{|c|}{ Frequency child bathed IN the lake } \\
\hline Once a day & 1943 & 65.2 \\
\hline
\end{tabular}


medRxiv preprint doi: https://doi.org/10.1101/2022.01.26.22269869; this version posted January 28, 2022. The copyright holder for this preprint (which was not certified by peer review) is the author/funder, who has granted medRxiv a license to display the preprint in It is made available under a CC-BY 4.0 International license .

Schistosomiasis in Rwanda pre-SAC

Once a week

Once a month

Once a year

Once in his life

Total

Child ever bathed using FETCHED lake water

No

Yes

Total
761

155

38

83

2980

947

3728

4675
25.5

5.2

1.3

2.8

100

20.3

79.7
184

185

186

187

188

189

190

191

192

193

194

195

196

197

198

199

200

201

202

203

204

97

\section{Prevalence and infection intensity of schistosomiasis among pre-school aged children}

Prevalence of schistosomiasis among pre-school aged children was assessed using both KK and POC-CCA. The POC-CCA results yielded a prevalence of $24 \%$ among children tested (trace results considered negative), while the KK only yielded a $0.8 \%$ prevalence. The POC-

CCA estimate was considered as the overall prevalence given the high sensitivity of the assay (16). For infection intensity, KK results were considered and the raw faecal worm egg count (FWEC) was multiplied by 24 to estimate the eggs per gram (epg) $(18,19)$. Based on WHO guidelines (20), 16.2\% $(n=6)$ of the 37 children who tested positive on Kato Katz had moderate infection while the rest had light infection (Table 3).

6

8 
medRxiv preprint doi: https://doi.org/10.1101/2022.01.26.22269869; this version posted January $28,2022$. The copyright holder for this preprint (which was not certified by peer review) is the author/funder, who has granted medRxiv a license to display the preprint in

perpetuity.
It is made available under a CC-BY 4.0 International license .

Schistosomiasis in Rwanda pre-SAC

205 Table 3. Prevalence and infection intensity of the study population

n

$\%$

\section{POC-CCA test}

Negative

3554

76

Positive

1121

24

Total

4675

100

\section{KK test results}

Negative

4638

99.2

Positive

0.8

Total

4675

100

\section{Intensity of infection}

Light

$$
31
$$

Moderate

$\begin{array}{ll}6 & 16.2\end{array}$

Heavy

$0 \quad 0$

Total

37

100

206 
medRxiv preprint doi: https://doi.org/10.1101/2022.01.26.22269869; this version posted January 28, 2022. The copyright holder for this preprint (which was not certified by peer review) is the author/funder, who has granted medRxiv a license to display the preprint in perpetuity.

It is made available under a CC-BY 4.0 International license.

Schistosomiasis in Rwanda pre-SAC

209

210

211

212

\section{Prevalence of schistosomiasis by age, gender, and location among pre-school children}

The results on the prevalence of schistosomiasis infection by gender revealed no statistically significant difference in infection between males and females. However, a statistically significant difference in infection was observed across age groups (Table 4).

Table 4. Infection prevalence per age category and gender

\begin{tabular}{|c|c|c|c|c|c|}
\hline & & \multicolumn{2}{|c|}{ CCA - traces considered negative } & \multicolumn{2}{|c|}{ KK } \\
\hline Age & & Negative & Positive & Negative & Positive \\
\hline \multirow[b]{2}{*}{$\leq 12$ months } & $\mathrm{n}$ & 52 & 21 & 73 & 0 \\
\hline & $\%$ & 1.5 & 1.9 & 1.6 & 0.0 \\
\hline \multirow[b]{2}{*}{ 13-24 months } & $\mathrm{n}$ & 617 & 225 & 841 & 1 \\
\hline & $\%$ & 17.4 & 20.1 & 18.1 & 2.7 \\
\hline \multirow[b]{2}{*}{ 25-36 months } & $\mathrm{n}$ & 915 & 315 & 1222 & 8 \\
\hline & $\%$ & 25.7 & 28.1 & 26.3 & 21.6 \\
\hline \multirow[b]{2}{*}{ 37-48 months } & $\mathrm{n}$ & 1068 & 291 & 1346 & 13 \\
\hline & $\%$ & 30.1 & 26.0 & 29.0 & 35.1 \\
\hline \multirow{3}{*}{$\geq 49$ months } & $\mathrm{n}$ & 902 & 269 & 1156 & 15 \\
\hline & $\%$ & 25.4 & 24.0 & 24.9 & 40.5 \\
\hline & & \multicolumn{2}{|c|}{$\chi^{2}(\mathrm{P}$-value $)=11.7493(\mathbf{0 . 0 1 9})$} & \multicolumn{2}{|c|}{$\begin{array}{c}\chi 2(\text { P-value })=9.7921 \\
(\mathbf{0 . 0 4 4})\end{array}$} \\
\hline \multicolumn{6}{|l|}{ Gender } \\
\hline \multirow[b]{2}{*}{ Female } & $\mathrm{n}$ & 1782 & 535 & 2298 & 19 \\
\hline & $\%$ & 50.1 & 47.7 & 49.5 & 51.4 \\
\hline \multirow{3}{*}{ Male } & $\mathrm{n}$ & 1772 & 586 & 2340 & 18 \\
\hline & $\%$ & 49.9 & 52.3 & 50.5 & 48.6 \\
\hline & & $\chi 2$ (P-valu & $0(0.158)$ & \multicolumn{2}{|c|}{$\begin{array}{c}\chi^{2}(\mathrm{P}-\text { value })=0.0478( \\
0.827)\end{array}$} \\
\hline
\end{tabular}

There were significant differences in infection prevalence across study sites, Gisagara District having the highest prevalence with $60.4 \%$, followed by Nyagatare and Gasabo Districts respectively with $46.8 \%$ and $40 \%$, while Kamonyi District had the lowest prevalence (7.1\%). Infection distribution across study sites is illustrated on Fig 1. 
medRxiv preprint doi: https://doi.org/10.1101/2022.01.26.22269869; this version posted January 28, 2022. The copyright holder for this preprint (which was not certified by peer review) is the author/funder, who has granted medRxiv a license to display the preprint in perpetuity

It is made available under a CC-BY 4.0 International license.

Schistosomiasis in Rwanda pre-SAC

226

227

228

229

230

231

232

233

\section{Factors associated with Schistosomiasis infection}

The logistic regression performed highlighted the age as a contributing factor to infection status as expected. In addition, two behavioural factors were significantly associated with the occurrence of infection: children taken care of by a sister and those who are bathed in the lake/pond are approximately 2 times more at risk of being infected $(\mathrm{OR}=1.9, \mathrm{p}<0.0001$ and $\mathrm{OR}=1.8, \mathrm{p}<0.0001$ respectively) compared to their counterparts.

Table 6. Association between behavioural factors and schistosomiasis

\begin{tabular}{rrrlrl}
\hline CCA_Results & Odds Ratio & Std. Err. & P & [95\% Conf. & Interval] \\
\hline \multicolumn{1}{l}{ Age group } & & & & & \\
$\leq 12$ months & REF & & & & \\
$13-24$ months & 0.800925 & 0.209265 & 0.3960 & 0.479945 & 1.336572 \\
25-36 months & 0.7182087 & 0.185582 & 0.2000 & 0.432816 & 1.191784 \\
37-48 months & 0.5782747 & 0.149883 & 0.0350 & 0.347946 & 0.961074 \\
$\geq 49$ months & 0.6029743 & 0.157244 & 0.0520 & 0.361678 & 1.005253
\end{tabular}

\section{Child carer}

\begin{tabular}{rrrrrr} 
Mum & \multicolumn{1}{l}{ REF } & & & & \\
Dad & 0.8052959 & 0.133487 & 0.1910 & 0.581915 & 1.114427 \\
Sister & 1.905744 & 0.323173 & $\mathbf{0 . 0 0 0 0}$ & 1.366845 & 2.657111 \\
Brother & 0.3749097 & 0.200035 & 0.0660 & 0.131754 & 1.066813 \\
Other & 0.5014567 & 0.05911 & 0.0000 & 0.398012 & 0.631787
\end{tabular}

\section{Child bathed in}

Lake

\begin{tabular}{rrrrrr} 
No & \multicolumn{1}{l}{ REF } & & & & \\
Yes & 1.825002 & 0.147079 & $\mathbf{0 . 0 0 0 0}$ & 1.558347 & 2.137286
\end{tabular}


medRxiv preprint doi: https://doi.org/10.1101/2022.01.26.22269869; this version posted January 28, 2022. The copyright holder for this preprint (which was not certified by peer review) is the author/funder, who has granted medRxiv a license to display the preprint in perpetuity.

\section{Knowledge on Schistosomiasis and perception on community based deworming}

Approximately $35 \%(n=1629)$ of parents/ caregivers had never heard of schistosomiasis (or

244 Bilharzia) before. However, out of the 155 community health workers (CHWs) interviewed,

$98.7 \%$ reported knowing the disease by name and $96.1 \%$ knew that it is contaminated through contact with water bodies and that pre-SAC are also at risk of contamination (Table 7).

Table 7. CHWs' general knowledge on schistosomiasis

\begin{tabular}{lcc}
\hline & $\mathbf{n}$ & $\mathbf{\%}$ \\
\hline Ever heard of Bilharzia & 2 & 1.3 \\
No & 153 & 98.7 \\
Yes & 155 & 100 \\
Total & & \\
& & \\
How is schistosomiasis/bilharzia acquired? & 6 & 3.9 \\
Don't know & 148 & 96.1 \\
Contact with water bodies & 154 & 100 \\
Total & & \\
& & \\
Can children under 5 years be infected? & 1 & 0.6 \\
No & 151 & 97.4 \\
Yes & 3 & 1.9 \\
Don't Know & 155 & 100 \\
Total & & \\
& & \\
\end{tabular}

250

251 Regarding the implementation of a community-based mass drug administration (MDA), $25262.1 \%(\mathrm{n}=95)$ of CHWs reported that this is implemented at their respective villages, while $25337.9 \%(n=58)$ reported that it is not. However, of those $(n=58$, i.e. $37.9 \%)$ who reported that 254 MDA is not yet implemented at their villages, $87.9 \%(n=51)$ strongly support the idea of 255 introducing it in their villages. Majority of the CHWs $(99.3 \%, n=136)$ reported that they are 256 willing to be involved in the implementation of community-based MDA campaigns in their 257 village and $77.9 \%(n=113)$ suggested that the village leader would be the best person to 258 coordinate this activity. CHWs also acknowledged some advantages of a community-based MDA such as full treatment coverage, time saving and an opportunity for health education 
medRxiv preprint doi: https://doi.org/10.1101/2022.01.26.22269869; this version posted January $28,2022$. The copyright holder for this preprint (which was not certified by peer review) is the author/funder, who has granted medRxiv a license to display the preprint in

perpetuity.
It is made available under a CC-BY 4.0 International license .

Schistosomiasis in Rwanda pre-SAC

260 (Table 8). However, some challenges were also highlighted such as the lack of distribution

261 spaces, poor management of drugs and poor knowledge of CHWs at the village level. 
medRxiv preprint doi: https://doi.org/10.1101/2022.01.26.22269869; this version posted January 28, 2022. The copyright holder for this preprint (which was not certified by peer review) is the author/funder, who has granted medRxiv a license to display the preprint in perpetuity.

Schistosomiasis in Rwanda pre-SAC

263

264

265

266

267

268

269

270

271

272

273

274

275

276

\section{Discussion}

The present study aimed to estimate the burden of schistosomiasis among pre-SAC in Rwanda and risk factors for the infection as well as to map the distribution of infection throughout the country for that category of population. This is the first comprehensive mapping exercise conducted in this young age group that has long been neglected by the Rwanda schistosomiasis control program. The study covered all the 17 Districts that had been highlighted by the previous school-based mapping as endemic areas $(16,17)$. The 80 study villages as minimum units of observation (sampling units) within these endemic Districts were purposively selected for their proximity to open water bodies to allow for the focal nature of the disease distribution. From the targeted districts, the results are presented at the level of study sites which have been extrapolated to administrative sectors based on the layout of open water bodies, environmental sanitary conditions and exposed population. Overall, the prevalence of schistosomiasis was $24 \%$ using the CCA diagnostic method and $0.8 \%$ using the KK method. This discrepancy was expected as the KK has shown a low sensitivity (21), especially in pre-SAC who are most likely carrying pre-patent and/or light infections (22). Nevertheless, the CCA prevalence detected was comparable to findings among SAC in the same areas (16), highlighting an urgent need to include these children in treatment campaigns. As expected, the distribution of infection was skewed, few Sectors harbouring most of the infection burden as highlighted by the significant differences between sites (i.e $60.5 \%$, maximum and $7.1 \%$, minimum). In agreement with the previous mapping among SAC $(16,17)$, sectors of Nyagatare and Gisagara Districts showed the highest infection prevalence (in 4 sectors the prevalence exceeded 50\%) but also the Districts of Ngoma, Bugesera, Gatsibo, Kayonza, Nyamasheke, Gicumbi and Karongi were heavily burdened. With regard to infection intensity, and based on WHO criteria (20), most of the pre-SAC showed light to moderate infection intensities. 
medRxiv preprint doi: https://doi.org/10.1101/2022.01.26.22269869; this version posted January 28, 2022. The copyright holder for this preprint (which was not certified by peer review) is the author/funder, who has granted medRxiv a license to display the preprint in perpetuity.

It is made available under a CC-BY 4.0 International license.

Schistosomiasis in Rwanda pre-SAC

In this study, $83.3 \%$ of parents/guardians fetched their water for domestic use from open importantly, $63.8 \%$ of the parents/guardians interviewed bath their children in open water bodies and our logistic regression analysis indicate that their children are twice as much likely to be infected compared to those who are not bathed in these waters. Previous studies elsewhere have also reported this passive nature of exposure to schistosomiasis among preafter by a sibling (a sister in this case) -most likely while their parents conduct domestic/professional chores- are more likely to be infected compared to those who are constantly with their mothers. Although we were not able to conduct a thorough observational investigation, these findings suggest that older sisters play and/or bath their younger siblings at water contact points that are far enough from where mothers wash dishes/clothes, and therefore far from detergents that may destroy cercaria (25). The latter may protect -to some extent- those children who are constantly with their mothers.

At the time of the study, $65 \%$ of the parents/caregivers had some vague information on schistosomiasis "yes I heard about schistosomiasis" but no extensive assessment of the level of knowledge was done. Nevertheless, more than $90 \%$ of $\mathrm{CHWs}$ reported that "schistosomiasis is transmitted through open waters". The study was however limited in terms of depth of health education assessment as the main focus was on screening infection in the child and interviewing the caregivers to assess exposure risk factors. Nevertheless, given the findings on infection prevalence, schistosomiasis control interventions are specifically needed that focus on health education for household members' behaviour change and practices to (a) limit the children's exposure to open water bodies, and (b) improve children's 
medRxiv preprint doi: https://doi.org/10.1101/2022.01.26.22269869; this version posted January 28, 2022. The copyright holder for this preprint (which was not certified by peer review) is the author/funder, who has granted medRxiv a license to display the preprint in perpetuity.

perpetuity. 4.0 International license.

Schistosomiasis in Rwanda pre-SAC

313

314

315

316

317

318

319

320

321

322

323

324

325

326

327

328

329

330

331

332

environmental sanitary conditions (26). Additional interventions such as provision of potable water supplies to these vulnerable communities as well as public latrines may provide longer term solutions. Indeed, more than $90 \%$ of the interviewed parents/guardians are farmers and most of our study sites were in close proximity to wetlands that are exploited for agriculture. Farmers generally spend several hours in the fields and, in the absence of latrines, are likely to defecate in these fields and contaminate the water bodies that are later used for bathing children.

The Rwandan Ministry of health has recently started implementing a community-based deworming that take place during the mother-child health $(\mathrm{MCH})$ week. Our study involved interviews of CHWs to find out how they perceive this deworming approach and findings indicate that they strongly support it and highlight several advantages. This should be the best way to reach pre-SAC once the pediatric formulation of Praziquantel is availed.

Taken together, the present study findings stress that pre-SAC in Rwanda are part of the population at risk of schistosomiasis and control interventions of the disease in Rwanda must include them. In particular, we provide a detailed map of pre-SAC infection distribution that should guide intervention strategies countrywide. Further assessment of the parents/CHW knowledge, attitudes and practices towards schistosomiasis and WASH recommended practices is warranted. 
medRxiv preprint doi: https://doi.org/10.1101/2022.01.26.22269869; this version posted January $28,2022$. The copyright holder for this preprint (which was not certified by peer review) is the author/funder, who has granted medRxiv a license to display the preprint in

perpetuity.
It is made available under a CC-BY 4.0 International license .

Schistosomiasis in Rwanda pre-SAC

335

336

337

338

339

340

341

342

343

344

345

346

347

348

349

350

351

352

353

354

355

356

357

358

\section{Acknowledgements}

This research was commissioned by the National Institute of Health Research (NIHR) Global

Health Research programme (16/136/33) using UK aid from the UK Government. The

authors would like to extend thanks to the study participants, the University of Rwanda,

Rwanda Biomedical Center, Ministry of Health, district hospitals and health centers for all

facilitations to the end of this research activity.

\section{Conflict of interest}

None

4


medRxiv preprint doi: https://doi.org/10.1101/2022.01.26.22269869; this version posted January 28, 2022. The copyright holder for this preprint (which was not certified by peer review) is the author/funder, who has granted medRxiv a license to display the preprint in

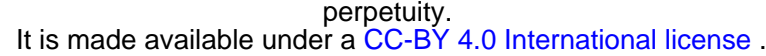

Schistosomiasis in Rwanda pre-SAC

360

361

362

363

364

365

366

367

368

369

370

371

372

\section{References}

1. Gasparotto J, Senger MR, Telles de Sá Moreira E, Brum PO, Carazza Kessler FG, Peixoto DO, et al. Neurological impairment caused by Schistosoma mansoni systemic infection exhibits early features of idiopathic neurodegenerative disease. The Journal of biological chemistry. 2021;100979.

2. Osakunor DNM, Mduluza T, Osei-Hyiaman D, Burgess K, Woolhouse MEJ, Mutapi F. Schistosoma haematobium infection is associated with alterations in energy and purine-related metabolism in preschool-aged children. PLoS neglected tropical diseases. 2020;14(12):e0008866.

3. Rujeni N, Morona D, Ruberanziza E, Mazigo HD. Schistosomiasis and soiltransmitted helminthiasis in Rwanda: An update on their epidemiology and control. Infectious Diseases of Poverty. 2017;6(1).

4. Engels D, Chitsulo L, Montresor A, Savioli L. The global epidemiological situation of schistosomiasis and new approaches to control and research. Acta Tropica. 2002;82(2):139-46.

5. Sokolow SH, Wood CL, Jones IJ, Swartz SJ, Lopez M, Hsieh MH, et al. Global Assessment of Schistosomiasis Control Over the Past Century Shows Targeting the Snail Intermediate Host Works Best. PLoS Neglected Tropical Diseases. 2016;10(7):1-19.

6. WHO. Ending-the-neglect-to-attain-the-SDGs--NTD-Roadmap. 2021;

7. Mutapi F, Rujeni N, Bourke C, Mitchell K, Appleby L, Nausch N, et al. Schistosoma haematobium treatment in 1-5 year old children: Safety and efficacy of the antihelminthic drug praziquantel. PLoS Neglected Tropical Diseases. 2011;5(5).

8. Imai N, Rujeni N, Nausch N, Bourke CD, Appleby LJ, Cowan G, et al. Exposure, infection, systemic cytokine levels and antibody responses in young children 
medRxiv preprint doi: https://doi.org/10.1101/2022.01.26.22269869; this version posted January 28, 2022. The copyright holder for this preprint (which was not certified by peer review) is the author/funder, who has granted medRxiv a license to display the preprint in

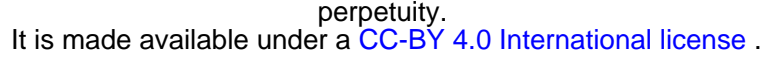

Schistosomiasis in Rwanda pre-SAC

concurrently exposed to schistosomiasis and malaria. Parasitology. 2011;138(12).

9. Rujeni N, Mazimpaka A, Tumusiime M, Nyandwi E, Rutayisire G, Kayiranga P, et al. Pre-school aged children are exposed to Schistosoma through Lake Kivu in Rwanda. AAS Open Research. 2019;

10. Stothard JR, Gabrielli AF. Schistosomiasis in African infants and preschool children: to treat or not to treat? Vol. 23, Trends in Parasitology. 2007. p. 83-6.

11. Poole H, Terlouw DJ, Naunje A, Mzembe K, Stanton M, Betson M, et al. Schistosomiasis in pre-school-age children and their mothers in Chikhwawa district, Malawi with notes on characterization of schistosomes and snails. Parasites and Vectors. 2014;

12. Sousa-figueiredo JC, Pleasant J, Day M, Betson M, Rollinson D, Montresor A, et al. Treatment of intestinal schistosomiasis in Ugandan preschool children : best diagnosis , treatment efficacy and side-effects, and an extended praziquantel dosing pole. 2010;2:103-13.

13. Ekpo UF, Oluwole AS, Abe EM, Etta HE, Olamiju F, Mafiana CF. Schistosomiasis in infants and pre-school-aged children in sub-Saharan Africa: Implication for control. Parasitology. 2012.

14. Ekpo UF, Laja-deile A, Oluwole AS, Sam-wobo SO, Mafiana CF. Urinary schistosomiasis among preschool children in a rural community near Abeokuta, Nigeria _ Parasites \& Vectors _ Full Text. 2010. p. 1-5.

15. World Health Organization (WHO). WHO Guideline on control and elimination of human schistosomiasis. Evidence-based recommendations. 2022.

16. Ruberanziza E, Wittmann U, Mbituyumuremyi A, Mutabazi A, Campbell CH, Colley DG, et al. Nationwide remapping of Schistosoma mansoni infection in Rwanda using circulating cathodic antigen rapid test: Taking steps toward elimination. American 
medRxiv preprint doi: https://doi.org/10.1101/2022.01.26.22269869; this version posted January 28, 2022. The copyright holder for this preprint (which was not certified by peer review) is the author/funder, who has granted medRxiv a license to display the preprint in perpetuity. 4.0 International license.

Schistosomiasis in Rwanda pre-SAC

Journal of Tropical Medicine and Hygiene. 2020;103(1):315-24.

17. Clark NJ, Umulisa I, Ruberanziza E, Owada K, Colley DG, Ortu G, et al. Mapping Schistosoma mansoni endemicity in Rwanda: A critical assessment of geographical disparities arising from circulating cathodic antigen versus Kato-Katz diagnostics. PLoS Neglected Tropical Diseases. 2019;

18. Barbosa CS, Gomes ECS, Marcelino JMR, Cavalcante KRLJ, Nascimento WRC. Quality control of the slides by Kato-Katz method for the parasitological diagnosis of schistosomiasis infection by Schistosoma mansoni. Jornal Brasileiro de Patologia e Medicina Laboratorial. 2017;53(2):110-4.

19. Leuenberger A, Nassoro T, Said K, Fenner L, Sikalengo G, Letang E, et al. Assessing stool quantities generated by three specific Kato-Katz thick smear templates employed in different settings. Infectious Diseases of Poverty. 2016;5(1):1-8.

20. Sturrock RF. Guidelines for the evaluation of soil-transmitted helminthiasis and schistosomiasis at community level: A guide for managers of control programmes. A. Montresor, DWT Crompton, DAP Bundy, A Hall \& L. Savioli. Geneva: World Health Organization, 1998. Transactions of the Royal Society of Tropical Medicine and Hygiene. 1998;92(4):470-1.

21. Oliveira WJ, Magalh C, Mariana A, Elias S, Castro VN De, Favero V, et al. Evaluation of diagnostic methods for the detection of intestinal schistosomiasis in endemic areas with low parasite loads : Saline gradient, Helmintex, Kato-Katz and rapid urine test. $2018 ; 1-22$.

22. Stothard JR, Sousa-figuereido JC, Betson M, Adriko M, Arinaitwe M, Rowell C, et al. Schistosoma mansoni Infections in Young Children : When Are Schistosome Antigens in Urine, Eggs in Stool and Antibodies to Eggs First Detectable ? 2011;5(1).

23. Osakunor DNM, Woolhouse MEJ, Mutapi F. Paediatric schistosomiasis : What we 
medRxiv preprint doi: https://doi.org/10.1101/2022.01.26.22269869; this version posted January $28,2022$. The copyright holder for this preprint (which was not certified by peer review) is the author/funder, who has granted medRxiv a license to display the preprint in It is made available under a CC-BY 4.0 International license .

Schistosomiasis in Rwanda pre-SAC

know and what we need to know. 2018;1-16.

436

24. Stothard JR; Gabrielli AF. Schistosomiasis in African infants and preschool children: to treat or not to treat? Trends Parasitology. 2007;(23):83-6.

25. Okwuosa, V N; Osuala FO. Toxicity of washing soaps to Schistosoma mansoni cercariae and effects of sublethal concentrations on infectivity in mice. Applied Parasitology. 1993;34(1):69-75.

441

26. World Health Organization (WHO). Children's Environmental Health Indicators 
medRxiv preprint doi: https://doi.org/10.1101/2022.01.26.22269869; this version posted January $28,2022$. The copyright holder for this preprint (which was not certified by peer review) is the author/funder, who has granted medRxiv a license to display the preprint in perpetuity.

It is made available under a CC-BY 4.0 International license.

Schistosomiasis in Rwanda pre-SAC

446 Supporting information caption

447 Fig 1. Map illustrating the distribution of schistosomiasis infection among pre-SAC in

448 Rwanda. Infection prevalence was based on CCA findings (trace as negative); Geographical

449 coordinates were collected for each site (village) and were extrapolated to the lowest

450 administrative boundary (sector).

451 
